\title{
Influence of iron preparations on occult blood tests ${ }^{1}$
}

\author{
D. G. ILLINGWORTH \\ Edinburgh
}

SYNOPSIS Ferrous fumarate (Fersamal) and ferrous carbonate (Ferrodic) may produce falsepositive results with the orthotolidine tablet tests (Occultest and Hematest) if administered to patients being investigated for alimentary bleeding. Misleading results are also likely if the benzidine test is employed as a filter-paper procedure. Ferrous sulphate, gluconate, succinate, iron and ammonium citrate, and other preparations of iron have no influence on the modern tablet tests for occult alimentary bleeding.

Orthotolidine, used for occult blood testing, is made up in two varieties of tablet: Occultest, the more sensitive, approximates in delicacy to the benzidine test of Schlesinger and Holst (1906) and it is usually employed in testing for haematuria ${ }^{2}$. The other product, Hematest, roughly corresponds to the slide test of Gregersen (1919) and is, therefore, much less sensitive, although intended by the manufacturers for occult blood tests on the faeces. A similar amount of orthotolidine is contained in each tablet and the manufacturers state that the increased sensitivity of Occultest tablets is achieved by adjusting the granulation of the ingredients and the hardness of the tablet.

Fielding and Langley (1958) explain that the calcium acetate and tartaric acid react on the addition of water to form hydrogen peroxide; haemoglobin will then exert a peroxidase-like effect to liberate active oxygen therefrom. The colourless orthotolidine behaves as an oxygen-accepter and is oxidized to a blue reaction product.

Inspection of the two types of tablet reveals that the more sensitive Occultest is of softer consistency. Unlike Hematest, and because it contains sodium bicarbonate, Occultest effervesces when in contact with water. Therefore, the orthotolidine content of Occultest comes in contact with the test smear more rapidly than that of Hematest. The Occultest tablets contain a red dye which, according to Free, Free, and Giordano (1956), prevents discolouration of the tablet and allows easier observation of the white filter paper for the blue colour which denotes a positive test.

${ }^{1}$ This article forms part of a thesis for which the author was awarded the degree of M.D. (with commendation) at Edinburgh University, 1963.

${ }^{2}$ Manufactured by the Ames Company Ltd.

Received for publication 6 July 1964.

\section{MATERIALS AND METHODS}

It was decided to employ the Occultest and Hematest orthotolidine procedures (Ames) to make tests in vitro on the various iron preparations in common use. Additionally, the benzidine test was performed, according to the Schlesinger and Holst (1906) method, in an attempt to resolve the controversial statements of former years. The medicines which pharmacists find presently popular are listed first, while those of a more whimsical nature follow (Table I). Secondly, volunteers passing negative stools on a meat-free diet were fed with iron preparations, including those which gave a positive result on direct testing. Their faeces were then re-tested with the Occultest, Hematest, and benzidine procedures (Table II).

TABLE I

RESULTS OF DIRECT TESTS ON IRON MEDICINES

Iron Medicine Results with

Occultest Hematest Benzidine

Ferrous sulphate

Ferrous gluconate (Fergon, Cerevon)

Colliron

Iron and ammonium citrate solution

Ferrous succinate (Ferromyn)

Ferrous fumarate (Fersamal)

Ferrous carbonate (Ferrodic,

Blaud's pill)

Plastules

Plastules with liver

Syrup ferri phosph. co.

Easton's Syrup

Ferro-Redoxon

Ferrous aminoaceto-sulphate

(Plesmet)

Iron calcium citrate (Rarical)

RESULTS

The results show that the ordinary iron medicines, such as ferrous sulphate and iron and ammonium 
TABLE II

RESULTS OF IRON FEEDING EXPERIMENTS

\begin{tabular}{|c|c|c|c|c|c|c|c|c|}
\hline $\begin{array}{l}\text { No. of } \\
\text { Subjects on } \\
\text { Special Diet }\end{array}$ & $\begin{array}{l}\text { No. of } \\
\text { Subjects } \\
\text { Passing } \\
\text { Negative } \\
\text { Stools }\end{array}$ & Iron Medicine & $\begin{array}{l}\text { No. } \\
\text { Occultest } \\
\text { Positive }\end{array}$ & $\begin{array}{l}\text { No. } \\
\text { Occultest } \\
\text { Negative }\end{array}$ & $\begin{array}{l}\text { No. } \\
\text { Hematest } \\
\text { Positive }\end{array}$ & $\begin{array}{l}\text { No. } \\
\text { Hematest } \\
\text { Negative }\end{array}$ & $\begin{array}{l}\text { No. } \\
\text { Benzidine } \\
\text { Positive }\end{array}$ & $\begin{array}{l}\text { No. } \\
\text { Benzidine } \\
\text { Negative }\end{array}$ \\
\hline $\begin{array}{r}12 \\
6 \\
5 \\
4\end{array}$ & $\begin{array}{r}12 \\
6 \\
5 \\
4\end{array}$ & $\begin{array}{l}\text { Ferrous sulphate } \\
\text { Iron and ammonium citrate } \\
\text { Ferrous fumarate (Fersamal) } \\
\text { Ferrous carbonate (Ferrodic) }\end{array}$ & $\begin{array}{l}0 \\
0 \\
5 \\
4\end{array}$ & $\begin{array}{r}12 \\
6 \\
0 \\
0\end{array}$ & $\begin{array}{l}0 \\
0 \\
2 \\
4\end{array}$ & $\begin{array}{r}12 \\
6 \\
3 \\
0\end{array}$ & $\begin{array}{l}\mathbf{0} \\
\mathbf{0} \\
\mathbf{0} \\
\mathbf{0}\end{array}$ & $\begin{array}{r}12 \\
6 \\
5 \\
4\end{array}$ \\
\hline
\end{tabular}

citrate solution, do not interfere with the occult blood tests, but that the newer, more elegant and expensive preparations, Fersamal (ferrous fumarate) and Ferrodic (ferrous carbonate), produce results which are comparable with those of blood. One other product, ferrous aminoacetosulphate (Plesmet) gives a positive benzidine test, but negative orthotolidine tests. The iron-feeding experiments also hint at a chemical difference, in the occult blood tests, with regard to their reaction with iron salts, inasmuch as, when iron, in the shape of ferrous fumarate or ferrous carbonate, is given to patients, it produces positive orthotolidine tests but negative benzidine tests in their stools.

\section{DISCUSSION}

It is deduced that the 'traditional' iron medicines may be administered at the same time as the performance of tests for faecal occult blood. If ferrous fumarate, currently marketed as Fersamal (Glaxo), is preferred in the treatment of irondeficiency anaemia (Swan and Jowett, 1959), then false-positive results may be obtained with the orthotolidine tests. This possibility was forecast shortly after the introduction of ferrous fumarate (Illingworth, 1959), and Holliday and Cuthill (1960) have described their difficulties in that connexion. Ferrous carbonate, once well known as Blaud's pill, has now been reincarnated as Ferrodic (Allen \& Hanbury) and here again false-positive results may be obtained with the orthotolidine tablet tests (Illingworth, 1961).

It is of interest that, with both these medicines, the ordinary benzidine test-tube method proves negative when applied to the stools of the persons under treatment. If, however, the test is performed on a piece of white filter paper a strong blue colour, i.e., a false-positive result, will be obtained. This anomaly is to be explained only by the fact that the blackness of stools containing iron obscures all other colowis in the test tube. Therefore, it is true to say that traditional iron medicines do not produce fal $\overrightarrow{86}-$ positive reactions with the test-tube methods; rather they make these tests less sensitive, owing the black colour of the faeces.

\section{CONCLUSIONS}

Past confusion about the effect of iron on occut blood tests has arisen because of the failure to perform a few obvious and simple tests. In the case of the Guaiac test, it is likely that an additional factor in the confusion has been the omission of the ether extraction technique. This oversight will leafd to false-positive Guaiac reactions (Johnson a ged Oliver, 1941).

With other tests, excluding orthotolidine techniques, there is no difficulty; iron medication of the anaemic patient does not produce false-positio results with occult blood tests on faeces. Confusion will, however, arise, with the modern orthotolidizi tablet tests, if the recently introduced ferrouts fumarate, or ferrous carbonate, should fe employed; these two drugs will also produce false-positive results if the benzidine test is carried out as a filter-paper technique.

\section{REFERENCES}

Fielding, H. E., and Langley, P. E. (1958). Amer. J. clin. Path., 30, 583. Free, H. M., Free, A. H., and Giordano, A. S. (1956). J. Und. (Baltimore), 75, 743.

Gregersen, J. P. (1919). Arch. Verdau.-Kr., 25, 169.

Holliday, T. D. S., and Cuthill, I. M. (1960). Brit. med. J., 2, 1310 Illingworth, D. G. (1959). Ibid., 2, 1099.

- (1961). Ibid., 2, 108.

Johnson, A. S., and Oliver, E. B. (1941). J. Lab. clin. Med., 26, 72要

Schlesinger, E., and Holst, F. (1906). Dtsch. med. Wschr., 32, 1444

Swan, H. T., and Jowett, G. H. (1959). Brit. med. J., 2, 782. 